\title{
Desorption of Indigosol Blue from Humic Acid Coated $\mathrm{Fe}_{3} \mathrm{O}_{4}$ Particles
}

\author{
Wachidah Nur Latifah*, Maya Rahmayanti \\ Chemistry Departement, Faculty of Science and Technology, UIN Sunan Kalijaga Yogyakarta \\ Jl. Marsda Adisutcipto No. 1 Yogyakarta 55281. Telp (0274) 558254. Fax (0274) 586117. \\ Email*: najmalateefa030@gmail.com
}

\begin{abstract}
Desorption of indigosol blue from humic acid coated $\mathrm{Fe}_{3} \mathrm{O}_{4}\left(\mathrm{Fe}_{3} \mathrm{O}_{4}-\mathrm{HA}\right)$ was investigated. The desorption had been done with $\mathrm{HCl}$ as desorption agent. The purpose of this study was to determine the effect of various concentration $\mathrm{HCl}$ on desorption efficiency of indigosol blue from $\mathrm{Fe}_{3} \mathrm{O}_{4}-\mathrm{HA}$. Desorption was carried out during 60 minutes of contact time. The result confirmed that $\mathrm{HCl}$ can be used as desorption agent although complete desorption can not be achieved, the desorption efficiency was $48.52 \%$ with concentration of $\mathrm{HCl} 1$ M.
\end{abstract}

Keywords: Desorption, $\mathrm{Fe}_{3} \mathrm{O}_{4}-\mathrm{AH}$, indigosol blue

\section{INTRODUCTION}

Synthetic dyes are usually used in many industries, including textile industries. Most dyes are stable to light, heat, and oxidizing agents. Removal dye from wastewater is a must for textile indutries because its hazardous, especially if the dyes added into water bodies. Currently, many methods like physical or chemical processes are used to treat dye in wastewaters.

Adsorption is one of effective methods for wastewater treatment. This method provide easy to apply, high efficient, low-cost, and the adsorbent can be reused or regenerated. Before regeneration process, the adsorbate had to released from the adsorbent with desorption agent. Desorption is a simple method using desorption agent therefore adsorbate can released.

Humic acid is one of alternative adsorbent for removal dye from aqueous solution because it contains $\mathrm{OH}$ and $-\mathrm{COOH}$ which can adsorb adsorbate with chemical or physical interaction. Humic acid in this study was isolated from Riau peat with alkali extraction. The humic acid coated with $\mathrm{Fe}_{3} \mathrm{O}_{4}$ for enhance the stability and improve the sorption of indigosol blue dye. After adsorption process, indigosol blue desorbed with $\mathrm{HCl}$ as agent desorption. $\mathrm{HCl}$ rarely be used as desorption of anionic dye and it would be novelty for this study. Desorption result indicated that $\mathrm{HCl}$ work as desorption agent because of ion exchange between adsorbent and adsorbate.

\section{MATERIALS AND METHODS}

\section{Materials}

The HA powders used were isolated from Riau peat with alkali extraction method. HA coated $\mathrm{Fe}_{3} \mathrm{O}_{4}$ nanoparticles with co-precipitation method. Indigosol blue was purchased from batik store at Kauman, Yogyakarta.

\section{Procedures}

Adsorption was carried out at optimum condition using thermostated shaker. After percentage of adsorption measured, the $\mathrm{Fe}_{3} \mathrm{O}_{4}-\mathrm{HA}$ was separated from liquid. The saturated $\mathrm{Fe}_{3} \mathrm{O}_{4}$ - $\mathrm{HA}$ were added into $\mathrm{HCl}$ with various concentration $0 \mathrm{M} ; 0.5 \mathrm{M} ; 1 \mathrm{M} ; 1.5 \mathrm{M}$; and $2 \mathrm{M}$. Desorption was carried out at room temperature and 60 minutes of contact time using thermostated shaker. The $\mathrm{Fe}_{3} \mathrm{O}_{4}$-HA separated from liquid then indigosol blue in liquid was measured with UV-Vis Spectrophotometer to estimate the desorbed amount of indigosol blue. The percentage of desorption was calculated using equation (Eq. (1))

\section{Percent of desorption $=$}

\section{Concentration of indigosol blue desorbed}

Concentration of indigosol blue adsorbed

$100 \%$

\section{RESULTS AND DISCUSSION}

\section{Adsorption study}

According to Fauzi (2018), adsorption process in this study was carried out at optimum condition. Based on FT-IR result (Figure 1.), (there was difference absorptions between $\mathrm{Fe}_{3} \mathrm{O}_{4}$ - $\mathrm{HA}$ before adsorption and. There was an absorption at wave number $1049.28 \mathrm{~cm}^{-1}$ indicated the stretched vibrate $\mathrm{S}-\mathrm{O}$ from $\mathrm{SO}_{3}-$ of indigosol blue therefore indigosol blue could be adsorbed by $\mathrm{Fe}_{3} \mathrm{O}_{4}$-HA. Percentage of adsorption reached up to $74.79 \%$. 


\section{Desorption study}

Desorption proccess is important to do because adsorbate have to release from adsorbent with desorption agent therefore the adsorbent can be used again. Desorption was done to understand the binding between the adsorbent and the adsorbate while adsorption proccess. In order to desorb the indigosol blue from $\mathrm{Fe} 3 \mathrm{O} 4-\mathrm{HA}, \mathrm{HCl}$ with various concentration was selected as desorption agent. The percentage of desorption indigosol blue as seen in Table 1.

Table 1. Percentage of desorption with various concentration of $\mathrm{HCl}$.

\begin{tabular}{ll}
\hline C of HCl & \% desorption \\
\hline 0 & 22.59 \\
0.5 & 25.06 \\
1 & 48.52 \\
1.5 & 31.23 \\
2 & 23.83 \\
\hline
\end{tabular}

From Table 1., $\mathrm{HCl}$ could be used as desorption agent of indigosol blue from $\mathrm{Fe}_{3} \mathrm{O}_{4}-\mathrm{HA}$ although the percentage of desorption achieved less than $50 \%$. $\mathrm{HCl}$ is a strong acid and had been used as desorption agent through ion exchange mechanism. $\mathrm{HCl}$ released its $\mathrm{H}^{+}$ ion and it would made an interaction with $\mathrm{SO}_{3}{ }^{-}$anion from indigosol blue. This interaction also happened between aquades as desorption agent but the $\mathrm{H}^{+}$ion from aquades was not strong enough to made an interaction with $\mathrm{SO}_{3}$ anion therefore the result was smaller than using $\mathrm{HCl}$.

Based on FT-IR result (Figure 1.), absorption at wave number $1627.92 \mathrm{~cm}^{-1}$ shifted to $1620.21 \mathrm{~cm}^{-1}$ indicated the interaction between $-\mathrm{COOH}$ from $\mathrm{Fe}_{3} \mathrm{O}_{4}-\mathrm{HA}$ and $\mathrm{SO}_{3}{ }^{-}$from indigosol blue decreased therefore the indigosol blue could be released from $\mathrm{Fe}_{3} \mathrm{O}_{4}-\mathrm{HA}$. The interaction between $\mathrm{Fe}_{3} \mathrm{O}_{4}$ - $\mathrm{HA}$ and indigosol blue was electrostatic interaction because indigosol blue could be released although didn't reach complete result. The interaction showed physic interaction between $-\mathrm{COOH}$ from $\mathrm{Fe}_{3} \mathrm{O}_{4}-\mathrm{HA}$ and $\mathrm{SO}_{3}{ }^{-}$from indigosol blue. The other interaction might be happened such as covalent bond between $\mathrm{Fe}_{3} \mathrm{O}_{4}$ - $\mathrm{HA}$ and indigosol blue because the absorption of stretched vibrate S-O could be seen at FTIR result.

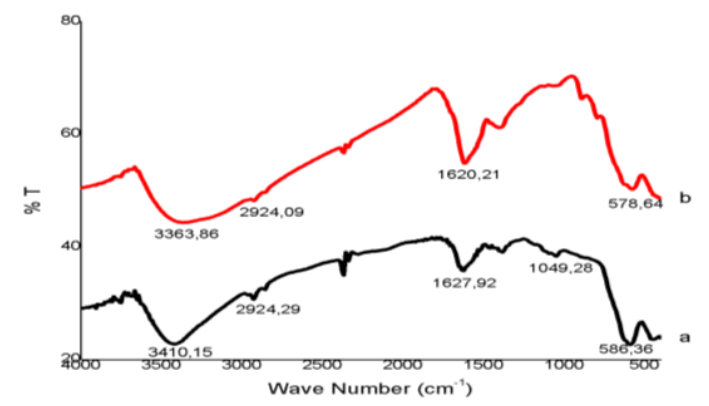

Figure 1. FT-IR result of (a) $\mathrm{Fe}_{3} \mathrm{O}_{4}$ - $\mathrm{HA}$ after adsorption (b) $\mathrm{Fe}_{3} \mathrm{O}_{4}$ - $\mathrm{HA}$ after desorption.

\section{CONCLUSIONS}

$\mathrm{HCl}$ can be used as desorption agent of indigosol blue from $\mathrm{Fe}_{3} \mathrm{O}_{4}$-HA with maximum result $48.52 \%$ with using $\mathrm{HCl} 1 \mathrm{M}$. Based on desorption result, the interaction might be happened between $\mathrm{Fe}_{3} \mathrm{O}_{4}$ - $\mathrm{HA}$ and indigosol blue was electrostatic interaction and covalent bond.

\section{ACKNOWLEDGEMENTES}

Thanks to the supervisor who always motivates and directs the writer.

\section{REFERENCES}

Areibat LEM, Kamari A, Din SM. 2018. Razor Clam (Ensis directus) Shell as a Low-Cost Adsorbent for Anionic and Cationic Dyes in Aqueous Solutions. International Journal of Enviromental Sciences and Development 9(12).

Fauzi RA. 2018. Adsorpsi Zat Warna Indigosol Blue O4B Menggunakan Asam Humat Termodifikasi Magnetit $\left(\mathrm{Fe}_{3} \mathrm{O}_{4}\right.$ AH). [Thesis]. UIN Sunan Kalijaga, Yogyakarta. [Indonesian]

Koesnarpadi, Serja SJ, Santosa D, Siswanta, B Sudiarso. 2015. Synthesis and Characterization of Magnetic Nanoparticles coated Humic Acid $\left(\mathrm{Fe}_{3} \mathrm{O}_{4}-\mathrm{AH}\right)$. Procedia Eviromental Sciences 30: 103-108.

Peng, Liang, Pufeng Qin, Ming Lei, Qingru Zeng, Huijuan Song, Jiao Yang. 2012. Modifying $\mathrm{Fe}_{3} \mathrm{O}_{4}$ Nanoparticles with Humic Acid for Removal of Rhodamine B in Water. Journal of Hazardous Materials 209-210; 193-198.

Sedyadi E, Khaerul H. 2016. Kajian Adsorpsi Remazol Yellow FG oleh Montmorillonit-Kitosan. //http:ejournal.uin.suka.ac.id//.

Stevenson FJ. 1994. Humus Chemistry: Genesis, Composition, Reactions. John Wiley \& Sons Inc, New York.

Zhang X, Panyue Z, Zhen W, Ling Z, Guangming Z, Chunjiao Z. 2013. Adsorption of Methylene Blue onto Humic Acid-Coated $\mathrm{Fe}_{3} \mathrm{O}_{4}$ Nanoparticles. //http:www.elsivier. om//. 